\title{
Proposed changes to the Planning Act and the implications for retail mezzanines: A problem from nowhere
}

Received (in revised form): 31 August 2005

\section{Jeremy Hinds}

is Head of Planning (Manchester) at FPD Savills.

\begin{abstract}
The government is proposing changes to the Planning Act to enable planning authorities to control proposals for new retail floor space. This is in response to the perception that there is a sudden increase in new retail floor space in retail parks that is being built at first-floor or mezzanine level as a result of planning decisions that appear to support arguments that such floor space does not require planning permission. Critics of the retail industry have highlighted the wording of the existing Planning Act as creating a loophole that has been exploited by retailers to the detriment of planning policy objectives which generally seek to encourage new retail investment in town centres and other similarly well-established retail locations. This paper examines whether in fact the perception is supported by the facts; and whether there is a need for the legislative change. It concludes that there is little evidence to support arguments that there is a widespread problem requiring legislative changes, and, further, the perception that a change is needed has become a selffulfilling prophecy. In short, the so-called mezzanine problem is a problem wrought from nowhere.
\end{abstract}

\section{Keywords:}

Planning act, mezzanine, retail, Northampton decision

Journal of Retail and Leisure Property (2006) 5, 117-120.

doi:10.1057/palgrave.rlp.5100005

Jeremy Hinds

Savills

Fountain Court 68 Fountain Street Manchester, M2 2FE, UK Tel: + 44 (o)161 2368644 Fax: + 44 (o)161 2280544 E-mail: JHinds@savills.com

\section{BACKGROUND}

As is widely understood, the definition of development contained in the Planning Acts excludes the creation of additional floor space where such floor space affects only the interior of the building and does not materially affect the external appearance of the building (s. 55(2)(a)). With this in mind, retailers have been adept at creating additional floor space at first 
floor level in existing retail warehouses, commonly in out of centre locations.

The advantage to the retailer is that creating new floor space in this way means they do not have to apply for planning permissions, and so can avoid having to address policy tests that seek to reduce the amount of retail floor space outside of established retail locations. As is widely understood, the policy tests relate to demonstrating that there is firstly a quantitative need for such new floor space; that the floor space cannot be provided in established retail locations; and that the new floor space would not harm the attraction of town centres in terms of future investment and customer activity. This last point is often summarised as harm to the vitality and viability of a centre.

Against this background, environmental groups and planning authorities generally have lobbied the government to amend the Act so as to require proposals for new floor space within buildings to be subject to the need for planning permission. The lobby groups have broadly succeeded, as the government intends to amend Section 55 by inserting a new clause which will require planning permission for additional floor space for proposals larger than $200 \mathrm{~m}^{2}$ where the proposed use of that floor space is for the use of retail sale of goods other than hot food. The amendment is clearly aimed at limiting new retail development, and is not intended to prevent new floor space for other commercial uses.

In the light of the above, the key questions are whether there is a need for the legislative amendment, and whether the effect of the amendment will have the desired outcome: that is, to limit the increase in out of centre retail floor space.

\section{WHETHER THERE IS A NEED FOR THE LEGISLATIVE AMENDMENT}

The background follows from a planning appeal case in September 2003, commonly known as Tamworth. In short, that case concerned the interpretation of a condition attached to a planning permission which at first reading appeared to restrict the amount of floor space that could be developed at the retail site. An application was made by Asda to increase the floor space, which was granted on appeal following the interpretation by the then inspector which held that the relevant condition could not be taken to mean that it prevented the new floor after the initial development had been completed. In short, the inspector concluded that if the intention of the condition had been to remove the rights to develop new floor space without applying for permission to do so, then the wording of the condition should have explicitly stated this.

The effect of that decision was to promote interest in creating mezzanine floors, and it was in response to this that environmental lobby groups and local authorities urged the government to amend the legislation as part of the wider reforms to the Planning Acts during the passage of the 2004 Planning Bill.

In particular, Friends of the Earth lobbied the Liberal Party during the committee stages of the Planning Reform Bill, and cited as evidence proposals by Asda to increase floor space in many of its stores. The 
government undertook to review the extent to which there could be a problem arising with the potential lack of planning control.

The review consisted of an informed survey of local planning authorities. The results of the survey are summarised in a consultation paper published in March 2005, and show that only 35 local authorities perceived there would be a future problem due to new floor space being built. Given that there are over 300 local authorities, the perceived problem relates to only about 10 per cent of the total.

Nevertheless, the government is proposing that a change is required, and so is suggesting that planning permission will be required for new floor space beyond the first $200 \mathrm{~m}^{2}$. It follows that proposals for $200 \mathrm{~m}^{2}$ or less will not require planning permission.

The publication of the consultation paper coincided with a High Court decision which for all practical purposes overturns the Tamworth case. The decision of Sullivan J in Northampton BC the Secretary for the Home Department and Land Securities Properties [2005] EWHC 168 (Admin) held that conditions purporting to limit floor space should be read in a common-sense way.

Such an approach accords with a broad run of High Court decisions on planning issues which remove the scope for legal interpretations, and which try to inject into the planning system the sense of normal, everyday language in understanding a planning permission and any conditions. In this sense, the Northampton decision overturns the approach adopted in the Tamworth case (setting aside the fact that Northampton decision was a High Court case and Tamworth was that of an appeal inspector).

It follows that the spur created by Tamworth for lobbying the government to change the 1990 Act has been removed by the Northampton case, and that there is now a strong argument in favour of leaving the existing legislative provisions untouched.

\section{WHETHER THE EFFECT OF THE AMENDMENT WILL HAVE THE DESIRED OUTCOME}

The desired outcome is clearly to limit uncontrolled development outside established retail locations. Two factors have conspired to undermine this objective, however: the fact is that there is a general lack of new floor space development at mezzanine level, and the change in case law brought about by the Northampton decision.

\section{General lack of New Development}

Despite comments by environmental groups, the reality is there has been a general reluctance by retailers to create additional floor space at mezzanine level. This largely reflects the practical difficulties that creating such floor space entails: namely disruption to trade and general operating procedures during construction and approvals relating to fire escapes, health and safety, heating, air flow etc. Retailers themselves are sceptical as to the economic benefits of such floor space: a number of retailers have abandoned proposals to add new floor space at mezzanine level because of evidence that they do not increase customer attraction, 
are expensive to maintain and operate and reduce the overall profitability of a store. Mezzanine floors are not a simple and easy answer to meeting retailing requirements for new floor space, and as such retailers have been generally reluctant to undertake the necessary investment.

The reality is that environmental lobby groups and the government have responded to a problem that in fact does not exist: they have relied only upon proposals by a handful of retailers that have in fact not transpired in practice.

\section{The change in case law}

Significantly, the Northampton decision has achieved the objective of lobby groups and the government by removing the ability of advancing the Tamworth-style arguments to promote proposals for new floor space. In short, the High Court has done the job for the government.

\section{CONCLUSION}

There is no evidence that retailers have used s.55 of the 1990 Act to develop new retail floor space either to the extent or in the manner envisaged and feared by lobby groups. In fact, the provisions of s.55 have long existed, and did not suddenly come to light as a result of the Tamworth case. The reality here was simply that the Tamworth decision coincided with the committee stages of the Planning Reform Bill, and as such an opportunity was created to restrict development by large format retailers that remain targets for lobby groups with a variety of political and environmental interests.

The government's own informal survey sheds no further light on the issues: with less than 10 per cent of planning authorities stating that they perceive there to be a problem, the only conclusion is that in reality no such problem exists. Interestingly, the informal survey was conducted before the Northampton decision, and it would be surprising if local authorities continued to state that they perceived there to be a problem.

The debate as to the need for planning control overlooks many important aspects of the role of planning authorities: if they considered problems would exist, then they should have imposed conditions in any event. Carefully worded conditions with clear meaning would avoid the need for government intervention.

Finally, retailers themselves remain circumspect as to the advantages of trading on upper floors. Evidence so far indicates that many retailers have not benefited from increasing their floor space in this way; indeed, the largest retailers have not invested in created mezzanine floors.

There is no doubt that the new provisions will create new powers for local authorities to control retail development. The real question is whether such controls are necessary. The answer is that they would be if the problem was a real one in the first place. 